О. И. Доценко, А. М. Мищенко

Донецикий национальный университет

\title{
ВЛИЯНИЕ НИЗКОЧАСТОТНОЙ ВИБРАЦИИ НА КИСЛОТНУЮ РЕЗИСТЕНТНОСТЬ ЭРИТРОЦИТОВ
}

Исследовано действие низкочастотной вибрации (диапазон частот 8-32 Гц, амплитуды 0,5 \pm 0,04 и $0,9 \pm 0,08$ мм) на кислотную резистентность эритроцитов. Охарактеризована кинетика отдельных стадий гемолиза. Оценены частотно-временные зависимости констант скоростей стадий гемолиза. Вибрация с частотами 8-16 Гц, амплитудой $0,5 \pm 0,04$ мм и 8 Гц, амплитудой 0,9 $\pm 0,08$ мм вызывает деструктивные перестройки водно-белкового состава цитоплазмы, приводящие к снижению барьера проницаемости для гемолитического агента. При вибрационном воздействии интервала частот 20-32 Гц, в результате окислительного стресса, преобладают реакции модифицирующего характера, приводящие к агрегации клеточных белков и, в частности, белка полосы 3.

\section{О. І. Доценко, А. М. Міщенко \\ Донецький наиіональний університет \\ ВПЛИВ НИЗЬКОЧАСТОТНОЇ ВІБРАЦЇ̈ НА КИСЛОТНУ РЕЗИСТЕНТНІСТЬ ЕРИТРОЦИТІВ}

Досліджено дію низькочастотної вібрації (діапазон частот 8-32 Гц, амплітуди 0,5 \pm 0,04 та 0,9 \pm 0,08 мм) на кислотну резистентність еритроцитів. Охарактеризовано кінетику окремих стадій гемолізу. Оцінено частотно-часові залежності констант швидкості стадій гемолізу. Вібрація з частотами 8-16 Гц, амплітудою 0,5 $\pm 0,04$ та 8 Гц, амплітудою $0,9 \pm 0,08$ мм викликас деструктивні перебудови водно-білкового складу цитоплазми, що викликає зниження бар'єру проникності для гемолітичного агента. При вібраційному впливі інтервалу частот 20-32 Гц, в результаті окислювального стресу, переважають реакції модифікувального характеру, що викликають агрегацію клітинних білків, зокрема білка смуги 3.

\section{O. I. Dotsenko, A. M. Mischenko Donetsk National University \\ INFLUENCE OF LOW-FREQUENCY VIBRATION ON THE ERYTHROCYTES ACID RESISTANCE}

The influence of low-frequency vibration (frequency range 8-32 $\mathrm{Hz}$, amplitudes $0.5 \pm 0.04$ and 0.9 $\pm 0.08 \mathbf{~ m m}$ ) on the erythrocytes' acid resistance was studied. The kinetics of various hemolysis stages was investigated. The time-frequency dependences of the kinetics constants of hemolysis stages were obtained and discussed. It was shown that 8-16 $\mathrm{Hz}$ vibration with the $0.5 \mathrm{~mm}$ amplitude and $8 \mathrm{~Hz}$ with $0.9 \mathrm{~mm}$ causes destructive reorganizations of a cytoplasm's water-protein structure. It leads to decrease in a permeability barrier for a hemolytic agent. As a result of oxidizing stress the vibration in the frequency range of 20-32 $\mathrm{Hz}$ causes the modifying reactions leading to the aggregation of cellular proteins and, in particular, the band 3 protein.

(С) О. И. Доценко, А. М. Мищенко, 2011 


\section{Введение}

Вибрация относится к факторам, обладающим высокой биологической активностью. Однако действие вибрации на изолированные клетки и ткани до сих пор не является предметом специальных исследований, хотя каждому исследователю должно быть ясно, что механизм биологического действия вибрации, как и других видов механических колебаний, не может быть разгадан до тех пор, пока не будет изучено ее действие на клетки.

И цитоплазма, и мембрана клетки содержат сеть полноразвернутых белков, поляризующих и структурирующих воду в многослойные образования $[5 ; 12 ; 15 ; 16]$. Такая система исключительно чувствительна к внешним воздействиям благодаря взаимосвязи колебаний «золь - гель» структур. «Золь - гель» структуры клетки - универсальный акцептор внешних электромагнитных полей, механических и гравитационных колебаний, который сохранил свою фундаментальную роль в эволюции и после появления специализированных рецепторных белков и рецепторных клеток [1; 15$]$. Участие воды в образовании единого водно-липидно-белкового комплекса и сенсорная способность реагировать на слабые (в том числе механические) воздействия, предопределяет ее функцию преобразования слабых внешних сигналов в изменение состояния активности кислородзависимых реакций в клетке. Активные формы кислорода (АФК), такие как супероксид-, гидроксилрадикалы и пероксиды, являющиеся промежуточными продуктами основного метаболизма, могут индуцировать окислительный стресс, который, в свою очередь, может приводить к изменениям и метаболическим перестройкам.

Информация о том, каким образом клетки реагируют на окислительный стресс, вызываемый низкочастотной вибрацией, в литературе отсутствует.

Для анализа влияния низкочастотной вибрации на состояние эритроцитов в работе использована оценка кинетических параметров кислотного гемолиза. Несмотря на то, что метод не новый, он достаточно часто применяется в научных исследованиях, особенно при изучении влияния лекарственных препаратов на состояние эритроцитов $[7 ; 10 ; 11]$. Однако часто авторы либо ограничиваются констатацией фактов, либо полученные результаты связывают с нарушением или изменением барьерной функции мембраны клетки.

Нужно отметить, что изучению механизма кислотного гемолиза посвящено несколько интересных работ [4; 8; 9], результаты которых указывают на вовлеченность в этот процесс ряда мембранных белков, в частности белка полосы 3 , белков цитоскелета и окислительных процессов с участием свободных радикалов [4]. Анализ данных гемолиза с этой точки зрения (то есть механизма процесса) позволяет выявить ряд скрытых структурных изменений в белках (если они есть), участвующих в процессе гемолиза, что и дает этому методу, наряду с простотой, ряд дополнительных преимуществ.

В связи с вышеизложенным цель работы состояла в изучении влияния низкочастотных механических колебаний в интервале частот 8-32 Гц с шагом 4 Гц, амплитудами $0,5 \pm 0,04$ и $0,9 \pm 0,08$ мм на резистентность эритроцитов к воздействию гемолитического агента $(\mathrm{HCl})$.

\section{Материал и методы исследований}

В экспериментах использовали свежую кровь доноров примерно одной возрастной группы и одного пола. Эритроциты осаждали центрифугированием. Затем эритроциты 4-кратно отмывали от плазмы $\mathrm{Na}$-фосфатным буфером $(0,015 \mathrm{M}, \mathrm{pH} 7,4)$, содержащим $0,15 \mathrm{M} \mathrm{NaCl}$. После центрифугирования удаляли надосадочную жидкость и белый опалесцирующий слой лейкоцитов, располагающийся над осадком эритроцитов. 
Эритроциты вносили в среду $0,15 \mathrm{M} \mathrm{NaCl}$ для получения суспензии с содержанием гемоглобина $1,1 \pm 0,16$ мг/мл. Суспензию эритроцитов подвергали действию вибрации в интервале частот 8-32 Гц, амплитудами $0,5 \pm 0,04$ и $0,9 \pm 0,08$ мм в течение трех часов. Вибрацию совершали при помощи вибростенда, разработанного на кафедре биофизики ДонНУ, состоящего из генератора низкочастотных сигналов синусоидальной формы, усилителя и механического преобразователя, совершающего колебания в вертикальной плоскости с заданной частотой и амплитудой. Экспериментальную кювету, заполненную суспензией эритроцитов, вертикально и прочно закрепляли на подвижной части вибратора (в этом случае механические колебания передаются в экспериментальную кювету с незначительными потерями мощности).

Изучение динамики кислотного гемолиза проводили на длине волны 650 нм (длина волны, при которой оптическая плотность образцов зависит от светорассеяния эритромассы). Измерения оптической плотности взвеси эритроцитов после добавления равного количества гемолитика производили с временным интервалом 1 с в автоматическом режиме. Измерение светопоглощения вели до получения совпадающих показаний оптической плотности, то есть до завершения гемолиза. По спектрам поглощения гемолиза рассчитывали первые производные спектров (эритрограммы), которые использовали для анализа положения и интенсивности максимумов эритрограмм. В качестве основных кинетических параметров, характеризующих структурные свойства эритроцитов, использовали кинетические параметры гемолиза - константу скорости лаг-фазы $\left(k_{l}\right)$ и константу скорости выхода гемоглобина из клетки (собственно гемолиза) $\left(k_{2}\right) . k_{1}=1 / t_{1}$, где $t_{1}$ - суммарное время подготовительных процессов и начала выхода гемоглобина. Скорость гемолиза эритроцитов хорошо описывается кинетическими уравнениями первого порядка с независящей от времени константой скорости $k_{2}$. В этом случае зависимость оптической плотности $D$ от времени $t$ описывается дифференциальным уравнением (1), решение которого (2) и логарифмическая линеаризация (3) позволяют определить константу скорости гемолиза.

$$
\begin{aligned}
& \frac{d D}{d t}=-k_{2} D, \\
& D_{t}=D_{0} e^{-k_{2} t}, \\
& \ln D_{t}=-k_{2} t+\ln D_{0} .
\end{aligned}
$$

Другие параметры, предлагаемые в литературных источниках $[7 ; 10 ; 11]$ для анализа, не отражают механизм процесса гемолиза.

Спектры поглощения гемолиза регистрировали до вибрационного воздействия (контроль), и затем каждые 20 минут в процессе эксперимента. Отдельно изучено трехчасовое влияние среды инкубирования на кинетические параметры гемолиза (далее в тексте - параметры, соответствующие частоте 0 Гц).

Все эксперименты выполнялись в трех повторностях. Статистический анализ полученных результатов проводили в программе Statistica. Достоверность различий между среднегрупповыми показателями оценивали с помощью непараметрического рангового критерия Уилкоксона и факторного анализа.

\section{Результаты и их обсуждение}

На рисунке 1 показаны зависимости константы скорости лаг-фазы гемолиза эритроцитов при вибрации с амплитудой $0,5 \pm 0,04$ мм в зависимости от двух факторов: частоты и времени вибрационного воздействия. Частоте 0 соответствует изменение этого параметра для контрольных серий экспериментов. Константа скорости лаг- 
фазы возрастает и в течение 3-го часа эксперимента, на 25,2 $\pm 2,4 \%$ превышает начальный уровень. Вибрационное воздействие в интервале частот 8-16 Гц вызывает еще больший прирост $k_{l}$ относительно начального уровня. Этот эффект дозозависимый, величины констант возрастают с увеличением времени и частоты воздействия. Воздействие с частотой 8 Гц приводит к росту констант скорости протекания лаг-фазы гемолиза к концу эксперимента на 29,2 $\pm 2,1 \%, 12$ Гц $-35,9 \pm 2,3 \%, 16$ Гц $-36,9 \pm 4,7 \%$. Далее в интервале частот 20-32 Гц с увеличением частоты вибрации степень увеличения констант лаг-фазы снижается. Вибрация с частотами 20, 24 Гц вызывает рост константы скорости лаг-фазы гемолиза, однако этот прирост не превышает $4 \%$ от начального уровня. Вибрация с частотой 28 Гц приводит к незначительному $(4,5 \pm 1,8 \%)$ росту константы скорости лаг-фазы в течение 2 часов воздействия, после чего она снижается до начального уровня. Вибрация с частотой 32 Гц не вызывает достоверных изменений константы скорости лаг-фазы по сравнением с начальным уровнем в течение 3 часов эксперимента.

A

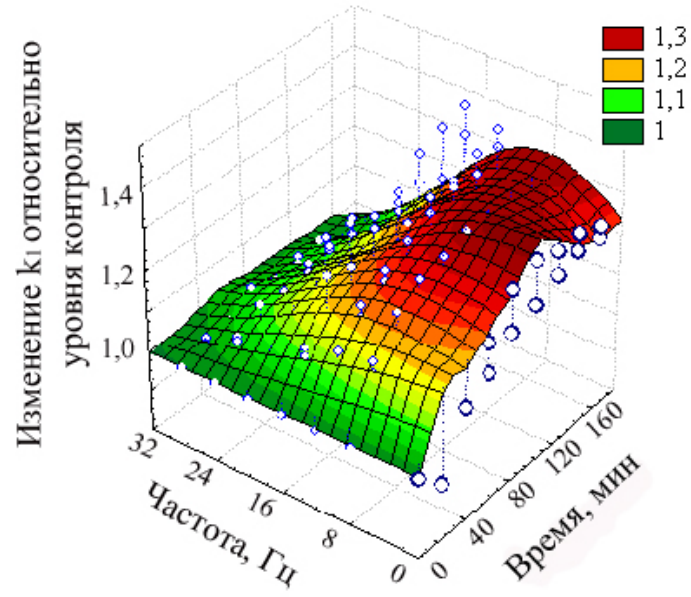

Б

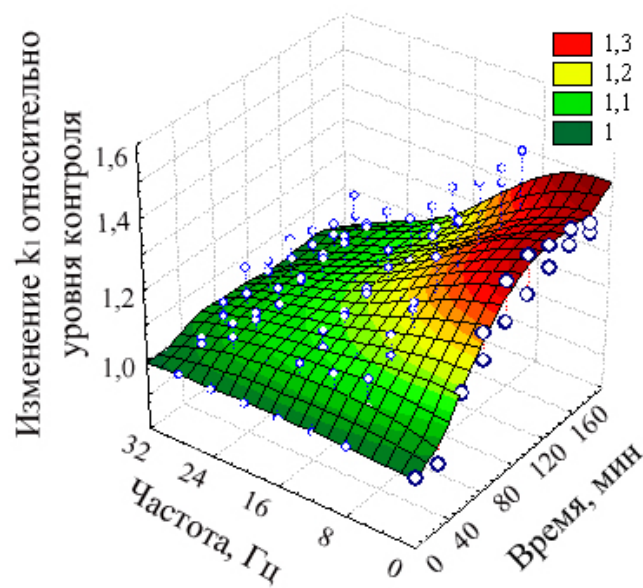

Рис. 1. Константы скорости лаг-фазы гемолиза в зависимости от частоты и длительности воздействия вибрации: $A$ - амплитуда вибрации $0,5 \pm 0,04$ мм, $Б$ - амплитуда вибрации $0,9 \pm 0,08$ мм

На рисунке 15 показаны изменения констант скорости лаг-фазы при вибрации с амплитудой $0,9 \pm 0,08$ мм. Получен похожий вид частотно-временной зависимости, однако максимальный прирост величины $k_{l}(46,7 \pm 4,1 \%)$ регистрируется при воздействии с частотой 8 Гц. Далее с увеличением частоты воздействия степень прироста константы скорости лаг-фазы гемолиза начинает снижаться. Воздействие с частотой 12 Гц вызывает увеличение $k_{l}$ в конце эксперимента только на $8,9 \pm 2,9 \%$. Вибрация с частотой 20 Гц приводит к незначительному росту (не более $4 \%$ ) константы скорости лаг-фазы в течение 80 минут эксперимента, после чего начинает снижаться и во временном промежутке 120-180 минут приближается к начальному уровню. При вибрации с частотой 32 Гц снижение константы скорости лаг-фазы относительно начального уровня составляет в среднем $5,9 \pm 3,5 \%$.

Установлено, что гемолизу, вызванному $\mathrm{HCl}$, предшествует перенос кислоты в цитозоль [4; 10]. Этот процесс идет с участием белка полосы 3. Прохождение $H^{+}$через анионный обменник является лимитирующей стадией и ингибирование белка полосы 3 
сильно влияет на скорость протекания лаг-фазы гемолиза (с увеличением степени ингибирования длительность предшествующего лизису этапа гемолиза возрастает). Согласно [4], любое воздействие, приводящее к увеличению ассоциации белка полосы 3 с компонентами клетки, также приводит к снижению скорости проникновения $H^{+}$в цитозоль и замедлению начала гемолиза.

Эритроциты, помещенные в среду, не содержащую глюкозу и ионы $K^{+}$, теряют ионы $K^{+}$, связанные с карбоксильными группами клеточных белков, быстро истощаются по АТФ, что ведет к локальной деполяризации внутриклеточной воды и переходу цитоплазмы из геля в золь [5]. Снижение барьера проницаемости для $H^{+}$будет приводить к увеличению скорости лаг-фазы, что мы и наблюдаем в контрольной серии. Наложение на этот процесс низкочастотных колебаний интервала частот 8-16 Гц низкой амплитуды (в нашем случае 0,5 $\pm 0,04$ мм) усиливает процессы, описанные выше. В интервале частот 20-32 Гц на процессы деполяризации накладываются возрастающие по интенсивности процессы образования активных форм кислорода. Окислительная модификация белка полосы 3 , ассоциация его окисленной формы с компонентами спектриновой сети клетки является в этом случае причиной снижения лаг-фазы процесса гемолиза в этом интервале частот. То, что низкочастотная вибрация интервала частот 24-32 Гц может вызывать окислительную модификацию белка в растворе, показано нами ранее $[2 ; 3]$.

На рисунке 2 показаны зависимости констант скоростей выхода гемоглобина при вибрации с амплитудой $0,5 \pm 0,04$ мм в зависимости от двух факторов; частоты и времени вибрационного воздействия. Для контрольных серий прирост $k_{2}$ в конце эксперимента составил $57,9 \pm 6,8 \%$. В процессе вибрационного воздействия в интервале 8-16 Гц прирост константы гемолиза ниже, чем в контрольной серии и снижается с увеличением частоты $(8$ Гц - 49,8 $\pm 8,4 \%, 12$ Гц - 48,1 $\pm 7,7 \%, 16$ Гц - 34,8 $\pm 11,6 \%, 20$ Гц - 18,7 \pm $9,3 \%$ ). Вибрация с частотами 24 и 28 Гц не приводит к достоверным изменениям константы скорости гемолиза по сравнению с начальным уровнем. При частоте 32 Гц обнаруживаются незначительные изменения в сторону роста значений констант гемолиза.

A

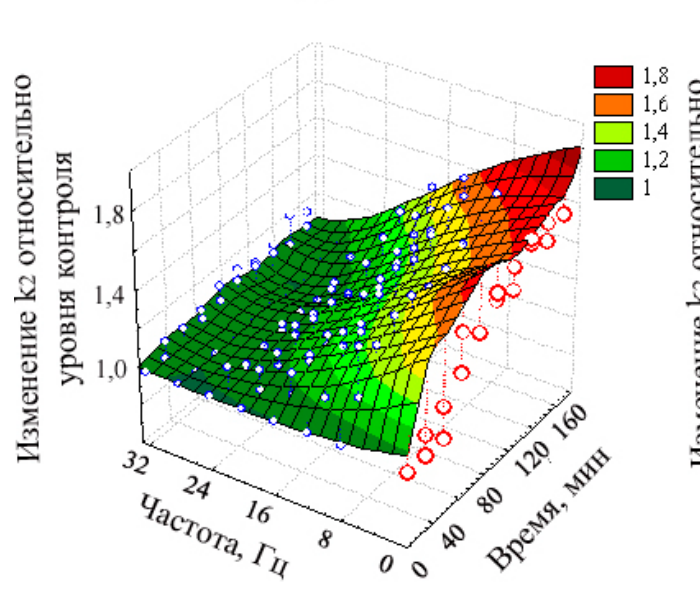

Б

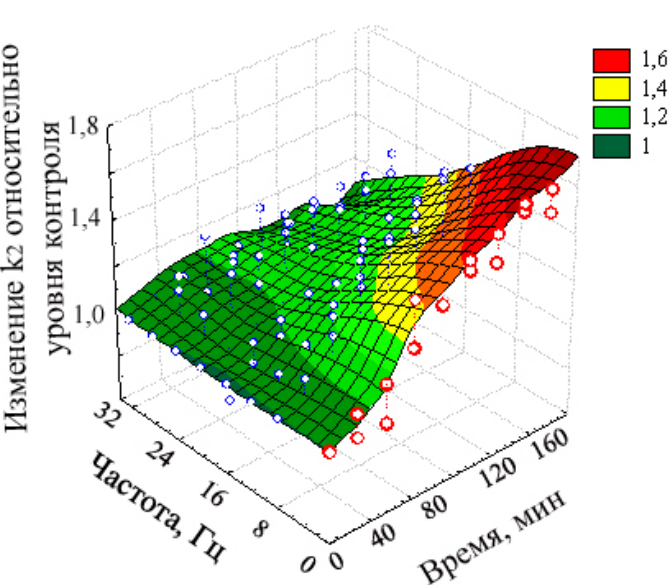

Рис. 2. Константы скорости выхода гемоглобина в зависимости от частоты и длительности воздействия вибрации: $A$ - амплитуда вибрации $0,5 \pm 0,04$ мм, $Б$ - амплитуда вибрации $0,9 \pm 0,08$ мм 
На рисунке $2 Б$ показаны изменения констант скоростей гемолиза при вибрации с амплитудой $0,9 \pm 0,08$ мм. И в этом случае константы гемолиза возрастают значительно в течение третьего часа эксперимента и степень увеличения констант гемолиза также определяется частотой вибрации. Как и в случае лаг-фазы прирост константы гемолиза выше контрольного уровня происходит только при вибрации с частотой 8 Гц. Во всех остальных случаях прирост константы гемолиза к концу эксперимента ниже, чем в контрольной серии, но выше, чем при тех же частотах с амплитудой $0,5 \pm 0,04$ мм; зависимость от частоты при этом обратная (12 Гц $-32,2 \pm 3,8 \%, 16$ Гц $-41,9 \pm 14,9 \%$, 20 Гц $-12,5 \pm 6,5 \%, 24$ Гц $-35,11 \pm 5,4 \%, 28$ Гц $-28,6 \pm 5,9 \%, 32$ Гц $-5,3 \pm 3,9 \%)$.

Центральный процесс кислотного гемолиза - расщепление гемоглобина с образованием мощного прооксиданта - гема. Процесс автоокисления гемоглобина сопряжен с образованием супероксиданион-радикала, дисмутирующего с образованием $\mathrm{H}_{2} \mathrm{O}_{2}$, способной вступать в реакцию Фентона. В связи с этим лизис эритроцитов в кислотной среде во многом обусловлен денатурацией и последующей агрегацией мембранных белков [4]. Участие мембранных белковых комплексов, в состав которых входит белок полосы 3 , в терминальной стадии гемолиза показано в работе [8]. Наблюдаемое снижение скорости гемолиза эритроцитов, подвергавшихся действию низкочастотной вибрации, может свидетельствовать об увеличении степени взаимодействий белка полосы 3 с компонентами клетки или его кластеризации, что находит отражение в уменьшении скорости денатурации белковых компонентов анионных каналов.

На рисунках 3-5 показано изменение эритрограмм эритроцитов, подвергаемых воздействию вибрации с частотами 16, 24 и 32 Гц при исследуемых амплитудах. При воздействии с частотой 16 Гц, амплитудой $0,5 \pm 0,04$ мм положение максимумов эритрограмм не постоянно и при увеличении времени вибрационного воздействия эритрограммы сдвигаются влево относительно контроля (рис. $3 A$ ). Форма эритрограмм, полученных для временных промежутков (20-180 минут) практически не отличается от контроля, что свидетельствует о деструктивных перестройках водно-белкового состава, ведущих к более быстрому проникновению гемолитического агента в эритроцит. Подобный характер эритрограмм отмечается и в экспериментах по воздействию вибрации с той же частотой и амплитудой $0,9 \pm 0,08$ мм (рис. $3 Б$ ).
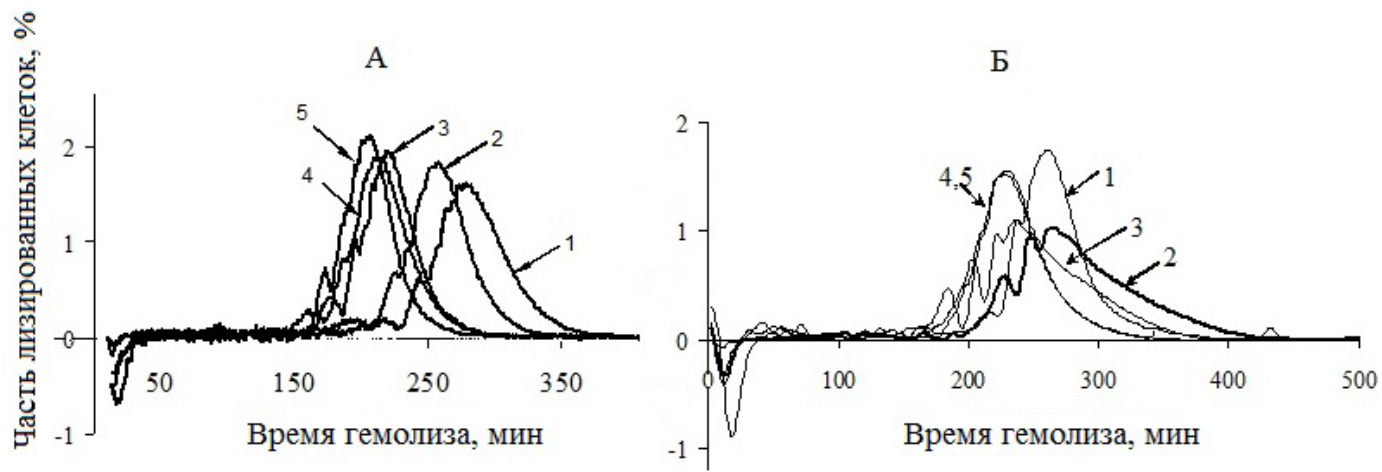

Рис. 3. Изменение эритрограмм в процессе воздействия вибрацией с частотой 16 Гц: $A$ - амплитуда $0,5 \pm 0,04$ мм: 1 - контроль, $2-20$ мин, $3-40$ мин, $4-100$ мин, $5-180$ мин; Б- амплитуда 0,9 $\pm 0,08$ мм: 1 - контроль, 2 - 20 мин, 3 - 60 мин, 4- 120 мин, 5 - 180 мин

Однако эритрограммы, полученные через 20 и 60 минут воздействия меняют форму, что находит отражение в снижении высоты основного пика и расширении полосы. Наблюдаемое перераспределение эритроцитов по стойкости без изменения вре- 
мени гемолиза указывает на то, что причиной является перестройка метаболизма в самих эритроцитах под действием вибрации. Последующее воздействие приводит к сдвигу эритрограмм влево (рис. 35 ).

На рисунках 4 и 5 показаны эритрограммы, полученные для эритроцитов, подвергавшихся вибрации с частотами 24 и 32 Гц, амплитудами $0,5 \pm 0,04$ и $0,9 \pm 0,08$ мм. В этом случае характерны в основном метаболические изменения внутри эритроцитов, что находит отражение в перераспределении эритроцитов по стойкости. Ранее было показано, что окислительная модификация белка в растворе наиболее выражена при воздействии с частотой 32 Гц [2]. В связи с этим мы предполагаем, что при вибрационном воздействии интервала частот 24-32 Гц преобладают реакции модифицирующего характера, приводящие к агрегации клеточных белков и, в частности белка полосы 3.
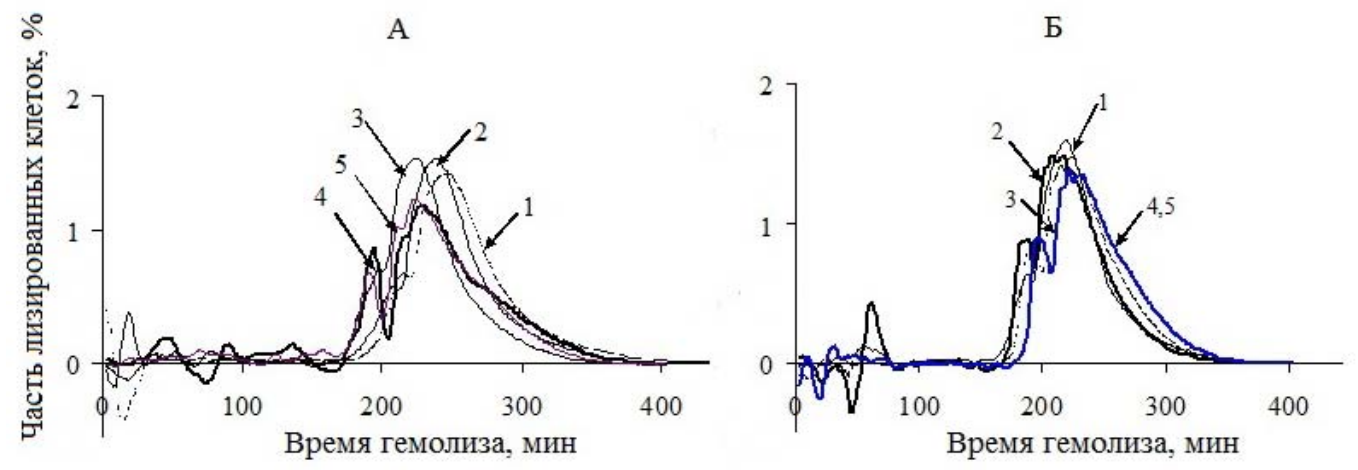

Рис. 4. Изменение эритрограмм в процессе воздействия вибрацией с частотой 24 Гц: $A$ - амплитуда $0,5 \pm 0,04$ мм: 1 - контроль, $2-20$ мин, $3-60$ мин, $4-120$ мин, 5 - 180 мин; 5 - амплитуда 0,9 \pm 0,08 мм: 1 - контроль, 2 - 60 мин, 3 - 120 мин, 4 - 140 мин, 5 - 180 мин
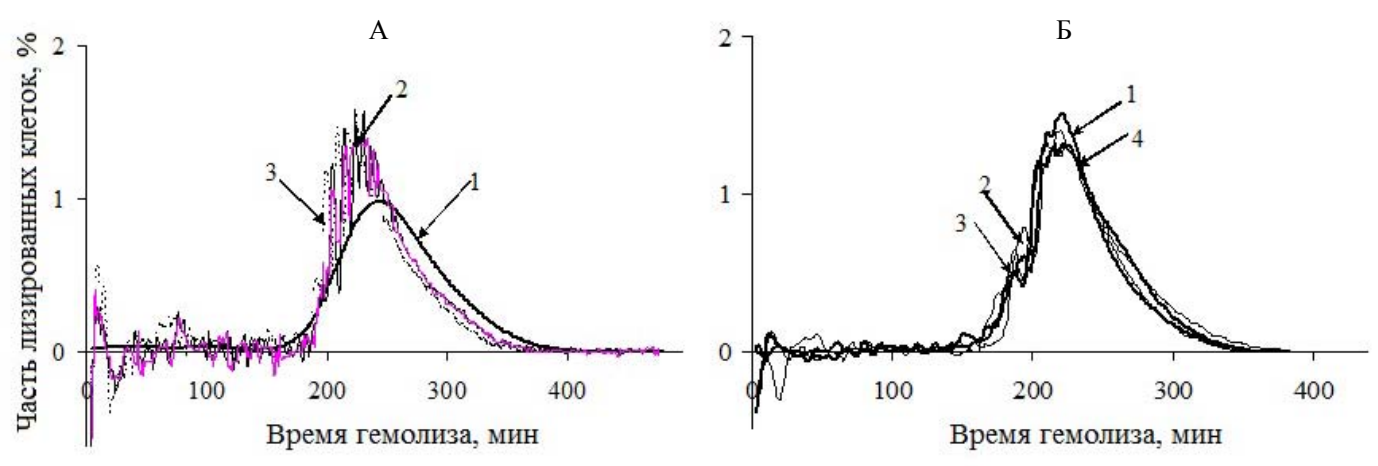

Рис. 5. Изменение эритрограмм в процессе воздействия вибрацией с частотой 32 Гц: $A$ - амплитуда 0,5 $\pm 0,04$ мм: 1 - контроль, $2-60$ мин, $3-160$ мин; 5 - амплитуда $0,9 \pm 0,08$ мм: 1 - контроль, $2-40$ мин, $3-80$ мин, $4-160$ мин

Обратимое образование временных структур в результате нативной агрегации белков является универсальной реакцией живой клетки на внешнее воздействие [13; 14]. Однако нативная агрегация, как и любой другой процесс в клетке, может быть объектом регуляции. Различные факторы могут вмешиваться в ее ход, инициируя возникновение новых сигнальных структур. Окислительный стресс может вызвать запуск в эритроцитах апоптозной программы, одним из признаков которой является изменение 
структуры и функций двух транспортных белков - гликофорина и белка полосы 3 и устойчивости клетки к действию гемолитических агентов [6]. По-видимому, в условиях вибрационного воздействия (интервал частот 24-32 Гц, амплитуда $0,5 \pm 0,04$ мм (эффект при воздействии с большей амплитудой менее выражен)) начинающийся некроз провоцирует переход к апоптическому сценарию гибели клетки.

Исходя из полученных данных и данных по окислительной модификации белков в условиях действия низкочастотной вибрации [2; 3], можно предположить, что в результате нативной агрегации в условиях действия вибрации с частотами 24-32 Гц возникают структуры, запускающие каскад реакций, необходимых для деградации клетки по механизму апоптоза.

\section{Выводы}

1. Характер структурных перестроек в эритроцитах существенно зависит от частоты и амплитуды механических колебаний.

2. Вибрация с частотами $8-16$ Гц, амплитудой $0,5 \pm 0,04$ мм и 8 Гц, амплитудой $0,9 \pm 0,08$ мм вызывает деструктивные перестройки водно-белкового состава цитоплазмы, приводящие к снижению барьера проницаемости для гемолитического агента.

3. При вибрационном воздействии интервала частот 20-32 Гц, в результате окислительного стресса, преобладают реакции модифицирующего характера, приводящие к агрегации клеточных белков и, в частности белка полосы 3. Следствием этих процессов является снижение констант скоростей отдельных стадий кислотного гемолиза эритроцитов.

\section{Библиографические ссылки}

1. Галль Л. Н. Механизм межмолекулярной передачи энергии и восприятия сверхслабых воздействий химическими и биологическими системами / Л. Н. Галль, Н. Р. Галль // Биофизика. 2009. - Т. 51, вып. 3. - С. 563-574.

2. Доценко О. I. Механохімічні процеси у водних розчинах альбуміну / О. І. Доценко, Д. В. Пронько // Проблемы экологии и охраны природы техногенного региона. - Донецк, 2008. - Вып. 8. - С. 281-290.

3. Доценко О. И. Изучение влияния низкочастотной вибрации на активность глутатионпероксидазы эритроцитов / О. И. Доценко, В. О. Ткаченко // Вестник Харьков. нац. ун-та им. В. Н. Каразина. Серия биология. - 2010. - Вып. 11 (№ 905). - С. 166-172.

4. Иванов И. Т. Сравнение механизмов кислотного и щелочного гемолиза эритроцитов человека // Биофизика. - 2001. - Т. 46, вып. 2. - С. 281-290.

5. Линг Г. Физическая теория живой клетки: незамеченная революция. - СПб : Наука, 2008. $-376 \mathrm{c}$.

6. Нарушение деформационных и транспортных характеристик эритроцитов при развитии у них апоптоза / И. В. Миндукшев, В. В. Кривошлык, А. А. Добрылко и др. // Биологические мембраны. - 2010. - Т. 27, № 1. - С. 28-38.

7. Нейропептид карнозин увеличивает устойчивость липопротеинов и эритроцитов крови и эффективность иммунокомпетентной системы у пациентов с хронической дисциркуляторной энцефалопатией / Т. Н. Федорова, М. С. Беляев, О. А. Трунова и др. // Биологические мембраны. -2008 . - Т. 25 , № 6. - С. 458-462.

8. Трикуленко А. В. Кинетика кислотного лизиса эритроцитов в присутствии лигандов некоторых интегральных белков плазматических мембран / А. В. Трикуленко, У. В. Панишко, Г. Л. Панкевич // Биофизика. - 1996. - Т. 41, вып. 6. - С. 1275-1277.

9. Трикуленко О. Кінетика кислотного лізису еритроцитів різних вікових популяцій за наявності лігандів деяких інтегральних білків плазматичних мембран / О. Трикуленко, У. Пінішко, Л. Дацюк // Вісник Львів. ун-ту. Серія біологія. -2001. - Т. 27. - С. 30-36. 
10. Холодов Д. Б. Молекулярные и клеточные механизмы действия натрия 2-[(2,6-дихлорфенил)амино]фенилсалицилат на клеточные мембраны / Д. Б. Холодов, В. А. Николаевский, С. Н. Шамарин // Сорбционные и хроматографические процессы. - 2009. - Т. 9. - Вып. 1. C. 137-146.

11. Холодов Д. Б. Изучение структурно-функциональных свойств мембран эритроцитов, модифицированных кеторолака трометамином / Д. Б. Холодов, В. А. Николаевский, С. Г. Резван // Вестник ВГУ. Химия. Биология. Фармация. - 2009. - № 1. - С. 129-135.

12. Structural and functional properties of hydration and confined water in membrane interfaces / E. A. Disalvo, F. Lairion, F. Martini et al. // Biochim et Biophys Acta (BBA) - Biomembranes. 2008. - Vol. 1778, N 12. - P. 2655-2670.

13. Matveev V. V. Protoreaction of protoplasm // Cell. Mol. Biol. - 2005. - Vol. 51. - P. 715-723.

14. Matveev V. V. Native aggregation as a cause of origin of temporary cellular structures needed for all forms of cellular activity, signaling and transformations // Theoretical Biology and Medical Modelling. - 2010. - Vol. 7, N 19.

15. Pollack G. H. The role of aqueous interfaces in the cell // Advances in Colloid and Interface Science. 2003. - Vol. 103. - P. 173-196.

16. Welch G. R. From protoplasmic theory to cellular systems biology: A 150-year reflection / G. R. Welch, J. S. Clegg // Am. J. Physiol. Cell Physiol. - 2010. - Vol. 298. - P. C1280-C1290.

Надійшла до редколегії 09.02.2011 